\title{
Can Robust Party Systems Rein Military Coups? Evidence from the New Democracies of the South
}

\author{
Mohammed Ezzat Rohiem ${ }^{1}$ \\ Teaching Assistant of Political Science \\ Faculty of Economics \& Political Science, Cairo University
}

\begin{abstract}
This paper investigates whether party systems can play a role in interpreting the high frequency of military coups d'etat in the countries of the South, concentrating on the new democracies of the South as a study sample. This study depends on three major characteristics of party systems; namely, fragmentation, polarization and turnout. Depending on data collected from 47 countries from Africa, Asia and Latin America, it has been found that fragmentation, voters turnout and civil society are significant predictors of military coups $d$ etat in the new democracies of the South. While no empirical evidence was found to support the significance of polarization.
\end{abstract}

Keywords: Party systems, Military Coups d etat, Fragmentation, Polarization, Turnout, Civil Society.

\section{Introduction}

Military coups detat have received a special academic concern starting from the second half of the twentieth century. Scholars explained the high frequency of military coups, depending on economic, social, historical and political factors. Yet party systems haven 't been sufficiently studied in the framework of military coups d'etatso far. It's a conventional wisdom that party politics has great importance for the process of the democratic transition and democratic consolidation. (Huntington, Sartori, Mainwaring and Scully, Lipset and Rokkan, Susan Scarrow, Myron Weiner and Joseph LaPalombara, Stephen White and Paul Webb among others). Thus, having dysfunctions in the party system and the structure of political competition raises some questions about the possible future consequences.On the other hand, civil society really matters in the context of democratic transition from dictatorships/authoritarian regimes to democratic ones. Civil society is that "network of groups and associations between families and state organizations [...]" (Cohen \&Arato, 1994; 48). Civil society is responsible for performing mediation roles between individuals and the state, as well as facilities initiating collective action. Thus, the absence of robust civil society opens the way for different forms of nondemocratic modes of governments. In the following, this paper theorizes for the relationship between party systems and civil societies on one hand, and military coups on the other, concentrating on the new democracies of the South. Moreover, the main hypotheses will be tested quantitatively on 47 countries from Africa, Asia and Latin America that witnessed successful or failed democratizationexperiences during the third wave of democracy (prevailed between 1974-1999), using Probit regression.

\section{Theory}

The main theory this study aims to investigate is that the weakness of political and social arenas may cause military coups detat in the countries of the globe south. Political arena is measured through party systems, while the social arena is measured through civil society. Moreover, the military leaders are considered as rational actors, they aspire to maximize their benefits and minimize their costs. The optimal interests of military leaders can be pursued through increasing their authority, prestige and returns, best achieved through ruling the country. Thus, military leaders are acting as rational actors in response to both the political and social arenas.

\section{Party systems and military coups}

A rapid glance at the political science literature may lead to a conclusion stating that party systems are sine qua non for democratic consolidation in both the well-established and the new representative democracies. In 
Mainwaring and Scully (1995) words; "it is difficult to sustain modern mass democracy without an institutionalized party system" (Mainwaring and Scully, 1995; 1, 2). Political parties are the main agents to deliver the people`s interests into the realm of public policies, as they represent voters preferences in public elections (Susan E. Scarrow, 1999; 276). Political parties play an important role in the process of political mobilization and participation, as well, through prompting people to vote (J. Karp \& S. Banducci, 2007; 217), as well as building the political identity of citizens (Ortiz, 2004; 14) through expressing their preferred partisan alignments and affiliation. More importantly for new countries, political parties promote the national integration process through transcending the parochial loyalties (ethnic, religious, racist, regional...etc.) and enhances] loyalty to the nation state. Moreover, it plays a big role in the political recruitment process through acting as de facto practicing field of politics, and then introduces future politicians and leaders. And therefore partisan politics is from prime importance for maintaining democratic forms of governments and is really laudable.

Talking about party systems is different from looking into political parties as organizations. As Hicken \& Kuhonta (2011) state; "when analysing party systems [...] we are looking primarily at the stability of patterned interactions among parties rather than at parties as organizational behemoths." (Hicken \& Kuhonta, 2011; 573). Party systems thus indicate the structure of political competition. A robust party system reflects stable inter-party competition, and vice versa. The distinction between party systems and political parties does not negate, at all, the mechanical connection between both of them. If party systems are the structure, then political parties are the units. Party systems are analysed through three major characteristics, namely; fragmentation, polarization and turnout.

Coming to the army, military leaders are supposed to be rational actors who are reacting in response to the situation of the political arena. In weak political competition structures, it's easier for military leaders to maximize their interests than in robust political thereof. As Huntington (1968) stated when analyzed the case of General Ne Win, during the instability periods of partisan competition, especially in non-established democracies, it`s more attainable for military leaders to market for themselves as the guardians of the national interest, and that "politics, parties and elections are corrupt; the military must intervene to clean them up" (Huntington, 1968; 244). The political arena may be captured through three major questions; (1) How many political parties shape the party system? (2) What is the nature of political competition between the major parties? Or in other words, how far away the political parties are from each other ideologically? As political competition between "centripetal" parties is supposed to be different from "centrifugal" (Sartori, 1976)and; (3) to what extent citizens participate in public elections through expressing their votes?The following part indicates the significance of each question.

\section{Party System Fragmentation}

Party system fragmentation means that the political power is divided on a big number of small political parties, with the inability of any of them to secure even a simple majority in public elections. In addition, fragmentation reflects deeper implications. Firstly,It reflects not only the ability of small parties to influence electoral outcomes, but also means that the linkage between voters and political parties, partisan appeals and even the nature of democratic decision making are all weak (Robin E. Best, 2007; 4).Secondly, having modest multiplicity implies stable political competition as well as majoritarian governments; while having high degrees of party system fragmentation means that the government is often coalitional, and then less stable (Lijphart, 2012; 63,64). Thirdly, fragmentation may be a proxy of deeper ethnic, cultural, linguistic or even geographical divisions (Lijphart, 2002; Jackman, 1978; Lipset and Rokkan, 1967; Sartori, 1976). Fourthly, severe multiplicity is a metaphor for that the majority of citizens are not able to determine who is the best to rule (Blais, 2006; 118), which make it depending all the time on compromise and negotiations between the different political groups using basis other than voters ' preferences. Fifthly, fragmented political elites are less likely to cooperate, and then to act collectively in case the military waged a coup. Therefore, fragmentation is supposed to have destabilizing effects, and then increasing the prospects of political instability and military coups d'etat in the non-yet established democracies. 
H1: Higher degrees of party system fragmentation increase the likelihood of military coups d'etat. (Positive Association)

\section{Political Polarization}

Political polarization refers to the positions of the political partieson the ideological continuum. The essence of political polarization revolves around having a long ideological distance between the major political parties. Although a comprehensive consensus on the impact of polarization cannot be captured, through having a propolarization camp (Dalton, 2008a; 2011b; Wang, 2012) and an anti-polarization counterpart (Sartori, 1976; Huntington, 1991; Lijphart, 1999), it can be deduced that the high degrees of polarization are not preferred. Political polarization refers to having 'centrifugal' political parties (Sartori, 1976). Such parties are positioned on the two far extremes, and then seek to attract extremist voters. Huntington (1991) considers, however, that having severe degrees of polarization is a threat to any democracy. Likewise, Lijphart (1999) adds that political polarization creates weak and unstable governments. While the other camp regards that polarization increases political participation ardently and fosters the popular engagement in politics through elections and then creates accountable governments (Wang, 2012; 689).

This study proposes that having high degrees of polarization have destabilizing effects for several reasons. Firstly, polarization reflects expected wide shifts in public policies in case that the other polarizers won in elections. Such shifts lead to volatile governmental policies and then instability. Secondly, polarization also makes it more likely to have deadlocks, especially when different institutions are dominated by different polarizers, which may recall the military to interfere. Latin America introduces typical experiences, where the breakdown of most of the democratic and semi democratic regimes has been because of party system polarization, and in some experiences triggered coups detat (Hagopian\& Mainwaring, 2005; 43). This is not only evidentin Latin America, but also recently in other regions, like Egypt. Experiences like Venezuela in 2002, as well as Egypt in 2013,are important in indicating how high degrees of polarizationmay,] lead to an imminent crack up of democracy. Polarization between the presidents`camp (Chavez and Morsi) and their opponents led the 2002 and 2013 coups, respectively, that have been waged by the military claiming alleged disengagement. This is in addition to Brazil, Argentina, Chile and Uruguay where polarization and the domination of the revolutionary left was replaced by military dictatorships (Hagopian\& Mainwaring, 2005; 44). Moreover, Sartori (1976) argues that high levels of polarization can end up at putting the whole regime's legitimacy under question. Thus, the second hypothesis this study aims to test is:

H2: Higher degrees of party system polarization increase the likelihood of military coups d'etat. (Positive Association)

\section{Voter Turnout}

Recent literature in comparative politics is teeming with studies explaining and analysing voterturnout. Turnout refers to how many people really vote in elections out of a giveneligible electorate. Generally, it can be considered thathigh and overtime stable rates of voter turnout are healthy for any democratic political system.

Voter turnout is influenced by a wide range of institutional as well socioeconomic factors. Institutional factors are asserted by many scholars (e.g. Blais, 2006; Blais\& Carty, 1990; Bingham, 1982a; 1986b, Jackman, 1987a; 1995b). The most common institutional factors are; if voting in elections is obligatory, if political parties have robust links with other groups like labour unions and syndicates, whether the parliament is composed of one or two chambers, the frequency of public elections and whether the given state has PR or majoritarian electoral system. However, theories of the institutional factors are still contradicted, creating shaky understanding of their implications (Blais, 2006; 116).

Thus, turnout is more supposed to be a proxy for broader socioeconomic factors. Education, standards of living and urbanization are highly significant factors influencing voter turnout (Blais, 2006; 117; Tenn, 2007; 446). This means higher turnout rates reflect higher educated, better livingcondition and more urbanized societies. Moreover, Deutsch (1961) stated that voter turnout is a significant indicator for the social mobilization process (Deutsch, 1961; 500). Voter turnout is therefore playing an important role to maintain the democratic system, while low and volatile rates of turnout indicates political dysfunctions and then have destabilizing effects (Czesnik, 2009; 107). Hence, the third hypothesis is: 


\section{H3: Higher levels of voter turnout decrease the likelihood of military coups d'etat. (Negative Association)}

\section{Civil society}

The basic logic standing behind civil society is the idea of the collective resistance and collective action. Considering the military leaders as rational actors that are highly interested in maximizing their benefits (defined by increasing returns, prestige and authority) and decreasing expected costs associated with waging a coup (defined primarily by the collective resistance, failure and then impeachment), they are supposed to react in response to the status of civil society organizations. Military leaders are decision makers that have the capacity to gather information and the resources to organize a plot. They have, in addition, highly equipped intelligence institutions (almost known as the military intelligence) giving the ability to obtain credible information. Thus, when civil society is perceived to be weak, the military leaders expect less resistance (less cost) and higher chances to maximize their authority and influence (high benefits), and then are encouraged to wage a coup. Then, the fourth hypothesis is:

\section{H4: Robust Civil Societies decrease the likelihood of military coups d'etat. (Negative Association)}

\section{Methods, Data and Measurement}

This study depends on quantitative design to test the four hypotheses. Probit regression is employed given that the dependent variable, coups, is dichotomous. The database is panel data. The dependent variable is military coups d'etat measured as a dummy; 0 if a given country didn't witness any attempted or successful coup during every single year and 1 otherwise. Data on military coups are taken from Jonathan M. Powell online dataset. The set of independent variables is fourfold; (1)Fragmentation is measured depending on Laakso \& Taagepera index depending on the effective number of parliamentary parties based on votes*. Data on fragmentation depends on self-calculations depending on elections results available by Deter Nohlen databases. (2) Polarization was measured by using POLARIZ variable used in Keefer, P., \&Stasavage, D. (2003). (3) Turnout data is retrieved from idea.int online dataset. And finally, (4) Civil society robustness was measured using Core Civil Society Index, as described in V-Dem online dataset.

A number of controls having nearly a consensus to be significant by past literature were included. Change in GDP per capita indicates the economic performance. A dummy is included to indicate if the regime is military. Instability is measured using banks index for instability. Change in military expenditures annually is measured to reflect if there is any grievance inside the army. Counterbalance forces are measured for as well as the size military personnel. Ethnic fractionalization index is included to measure for ethnic divisions. Two dummies are included to measure if the given case was a former British/French colony. And finally, a control measuring whether there`s a civil war on set is employed. Change in per capita GDP, Banks index for instability, change in military expenditures as well as the size of the military personnel are all taken from Jonathan M. Powell (2012). While military regime dummy and the counterbalance forces are taken from Belkin\&Schofer (2003). Ethnic fractionalization, colony measures as well as the civil war onset thereof are taken from Fearon\&Laitin (2003).

The sample employed consists of 47 new democracies from Africa, Asia and Latin America* during the period(1974-2014). The 47 countries are selected based on their democratic transition based on Polity score. A new democracy is procedurally defined as a country that transformed from minus to plus polity scores during the period (1974-1999). However, only countries of the South were included given that studying military coups in the north is not justifiable. Non-democratic periods as well as the one-party periods in African countries were excluded to make sure that the political system tolerated minimal rates of democratic competition.

\footnotetext{
* For unavailable data on some African countries, the index was calculated based on number of votes given that the difference is significantly small and that the main focus is not studying electoral systems.

* From Latin America: Haiti, Dominican Republic, Mexico, Guatemala, Honduras, El Salvador, Nicaragua, Panama, Guyana, Suriname, Ecuador, Peru, Brazil, Bolivia, Paraguay, Chile, Argentina and Uruguay. From Africa: Cape Verde, Guinea-Bissau, Mali, Benin, Niger, Ivory Coast, Sierra Leone, Ghana, Nigeria, Central African Republic, Congo, Mozambique, Zambia, Malawi, Lesotho, Madagascar and Comoros. From Asia: Mongolia, Taiwan, South Korea, Pakistan, Bangladesh, Nepal, Thailand, Cambodia, Philippines, Indonesia, and Fiji.
} 


\section{Findings}

Findings are described in the table (1). Results indicate that fragmentation, turnout and civil society are all significant predictors of military coups d etat in the countries of the South, while there is no empirical evidence that polarization is significant. Model 1 tests the impact of the IVs on the military coups generally regardless the outcome (failure/success). Coefficients of Probit regressions aren't as simple as their counterparts in OLS regressions, and therefore the exact impact magnitude can only be knownby calculating the marginal effects. The marginal effect coefficient of fragmentation is 0.03 , indicating that a one point increase in fragmentation increases the likelihood of coups by $3 \%$ (positive and significant relationship on the $90 \%$ level). Turnout despite being very significant (on the $99 \%$ level), its marginal effect coefficient is only -0.005 , indicating that a one point increase in the turnout decreases the likelihood of military coups by only $0.5 \%$ (negative and significant on the $99 \%$ level). Civil society accounts for the biggest impact magnitude. Its marginal coefficient is -0.364 , indicating that a one point increase in civil society index decreases the likelihood of military coups by more than $36 \%$ (negative and significant on the 95\% level). This indicates that the three hypotheses areempirically supported. So, the relationship between military coups and fragmentation is positive, while it has a negative relationship with both of turnout and civil society. Trying to test the significance of the three variables on the outcome of the coup (whether it will be a failure or success), it has been found that the only significant variable in predicting the outcome is civil society. The marginal coefficient for civil society is -0.434 , indicating that a one point increase in civil society decreases the likelihood of coups success by more than $43 \%$ on the $99 \%$. This may be interpreted as the theory proposes according to the collective resistance and collective action hypothesis, that robust civil society is more able to organize collective resistance and to declare disobedience to the plotters orders. This is supposed to increase the likelihood of their failure and being trailed.

Findings stated below are consistent with the most important works that tested for similar variables. Jackman (1978) tested for the impact of multipartyism (tested for here through fragmentation) and political participation (tested for using turnout). Jackman found that societies having more multipartyism and higher political participation are less likely to witness military coups (Jackman, 1978; 7). Johnson et al (1984) replicated Jackman`s study with wider dataset, ending up to the same conclusion. Civil society impact is also consistent with what Belkin and Schofer (2003) found. They`ve found that civil society is a significant predictor of military coups d'etat. However, they measured civil society through associational membership in INGOs, which cannot be considered as sets of resistance.

To sum up, this study ends up to two main conclusions; firstly, when the political arena is weak, characterized by dysfunctions in the political competition structure as well as the inability of the political elites to organize the political life effectively, this gives more chances to the army to expand their influence and to go out of their barracks. Secondly, when social arena is weak, characterized by weak civil society organizations, the army expects less resistance, then they are more encouraged to wage a coup in such societies, knowing that their chances to succeed in the takeover are high.

\section{Acknowledgements}

This paper summarizes the logic of my MA thesis. I hereby thank my supervisor, Professor Mazen Hassan so much for his support, patience and inspiration. He always welcomed giving his time and energy to read, to provide references and books and to give me his feedback even when he is abroad. However, I take full credit of any mistakes. 
International Conference on Studies in Humanities and Social Sciences (SHSS-2016) May 24-25, 2016 Paris (France)

Table (1): Probit Regression for Attempted and Successful Coups (1974-2014)

\begin{tabular}{lcc}
\hline \multirow{2}{*}{ Variables } & \multicolumn{2}{c}{ Military Coups } \\
\cline { 2 - 3 } & Model 1 & Model 2 \\
& (Attempt) & (Success) \\
\hline Fragmentation & $\mathbf{0 . 3 6 *}$ & $\mathbf{- 0 . 0 6}$ \\
& $(0.2)$ & $(0.3)$ \\
Polarization & $\mathbf{- 0 . 9}$ & - \\
Turnout & $(0.6)$ & $\mathbf{- 0 . 0 4 4}$ \\
& $\mathbf{- 0 . 0 5 7 * * *}$ & $(0.02)$ \\
Civil Society & $(0.02)$ & $\mathbf{- 6 . 6 * * *}$ \\
& & $(2.3)$ \\
Party System Institutionalization & $\mathbf{- 4 . 3 5 * *}$ & $\mathbf{1 . 2}$ \\
Index & $(2)$ & $(1.2)$
\end{tabular}

\section{$\underline{\text { Controls }}$}

Ch. GDP/Per Capita

Instability

Ch. Mil. Expenditures

Mil. Personnel

Military Regime

Ethnic Fractionalization

Counterbalance

Former French Colony

Former British Colony

Civil War onset

Constant

Observations

Pseudo R2

Robust standard errors in parentheses

Two-tailed t-test.
4

(2.7)

$\mathbf{- 8 . 4 3 e - 0 5}$

(0.0001)

$-1.6$

(1.03)

$-1.46 * * *$

(0.34)

$1.804 * *$

(0.789)

$8.5 * * *$

(2.07)

$\mathbf{- 0 . 5 1} * *$

$(0.21)$

$-5.7 * * *$

(1.9)

$-2.52 * *$

(1.06)

$2.4 * * *$

(0.85)

3.3*

(1.9)

170

0.53
(3.1)

$-3.94 \mathrm{e}-05$

(0.0001)

$-3.3 * *$

(1.4)

$-1.5 * * *$

$(0.4)$

$2.1 * * *$

$(0.66)$

10.06****

(2.6)

$-1 * * *$

$(0.35)$

$-5.1 * * *$

(1.9)

$-1.9$

(1.2)

$3.3 * * *$

$(0.9)$

3.18

(2.2)

162

0.56

$* * * \mathrm{p}<0.01, * * \mathrm{p}<0.05, * \mathrm{p}<0.1$ Confidence Interval: $90 \%$

Model 1 measures the dependent variable attempt. Model 2 measures the dependent variable success. Attempt means the attempted coups detat, while success means the successful thereof. 


\section{References}

[1] Belkin, A., \&Schofer, E. (2003). Toward a structural understanding of coup risk. Journal of Conflict Resolution, 47(5), 594-620.

http://dx.doi.org/10.1177/0022002703258197

[2] Best, R. E. (2007). Political Parties, Voters, and Institutions: An Examination of Party System Fragmentation in Advanced Democracies, 1950--2005. ProQuest.

[3] Blais, A., \& Carty, R. K. (1990). Does proportional representation foster voter turnout?. European Journal of Political Research, 18(2), 167-181.

http://dx.doi.org/10.1111/j.1475-6765.1990.tb00227.x

[4] Blais, A. (2006). What affects voter turnout?. Annu. Rev. Polit. Sci., 9, 111-125.

http://dx.doi.org/10.1146/annurev.polisci.9.070204.105121

[5] Cohen, J. L., \&Arato, A. (1994). Civil society and political theory. Mit Press.

[6] Cześnik, M. (2009). Voter turnout Stability—Evidence from poland. Polish Sociological Review, 107-122.

[7] Dalton, R. J. (2008). The quantity and the quality of party systems party system polarization, its measurement, and its consequences. Comparative Political Studies, 41(7), 899-920.

http://dx.doi.org/10.1177/0010414008315860

[8] Hagopian, F., \& Mainwaring, S. P. (Eds.). (2005). The third wave of democratization in Latin America: advances and setbacks. Cambridge University Press. http://dx.doi.org/10.1017/cbo9780511791116

[9] Hicken, A., \& Kuhonta, E. M. (2011). Shadows from the past: Party system institutionalization in Asia. Comparative Political Studies, 0010414010396460.

http://dx.doi.org/10.1177/0010414010396460

[10] Huntington, S. P. (1993). The third wave: Democratization in the late twentieth century (Vol. 4). University of Oklahoma press.

[11] Jackman, R. W. (1978). The predictability of coups d'etat: a model with African data. American Political Science Review, 72(04), 1262-1275.

http://dx.doi.org/10.2307/1954538

[12] Jackman, R. W. (1987). Political institutions and voter turnout in the industrial democracies. American Political Science Review, 81(02), 405-423.

http://dx.doi.org/10.2307/1961959

[13] Jackman, R. W., \& Miller, R. A. (1995). Voter turnout in the industrial democracies during the 1980s. Comparative Political Studies, 27(4), 467-492.

http://dx.doi.org/10.1177/0010414095027004001

[14] Johnson, T. H., Slater, R. O., \& McGowan, P. (1983). Explaining African military coups d'etat, 1960-1982. American Political Science Review, 78(03), 622-640.

http://dx.doi.org/10.2307/1961833

[15] Karp, J. A., \&Banducci, S. A. (2007). Party mobilization and political participation in new and old democracies. Party Politics, 13(2), 217-234. http://dx.doi.org/10.1177/1354068807073874

[16] Keefer, P., \&Stasavage, D. (2003). The limits of delegation: Veto players, central bank independence, and the credibility of monetary policy. American political science review, 97(03), 407-423.

http://dx.doi.org/10.1017/S0003055403000777

[17] Lijphart, A. (2012). Patterns of democracy: Government forms and performance in thirty-six countries. Yale University Press.

[18] Mainwaring, S., \& Scully, T. R. (Eds.). (1995). Building democratic institutions: Party systems in Latin America (pp. 1-36). Stanford: Stanford University Press.

[19] Powell, G. B. (1982). Comparative democracies: Participation, stability and violence. Cambridge, MA. 
[20] Powell, G. B. (1986). American voter turnout in comparative perspective.American Political Science Review, 80(01), $17-43$.

http://dx.doi.org/10.2307/1957082

[21] Samuel, P. Huntington, Political Order in Changing Societies (New Haven, 1968). Huntington Political Order in Changing Societies1968.

[22] Scarrow S. E. (1999), Democracy within and without parties, Party Politics, Vol. 5 No. 3, pp. 275-282. http://dx.doi.org/10.1177/1354068899005003001

[23] Tenn, S. (2007). The effect of education on voter turnout. Political Analysis,15(4), 446-464. http://dx.doi.org/10.1093/pan/mpm012

[24] Wang, C. H. (2012). The effects of party fractionalization and party polarization on democracy. Party Politics, 1354068812448691. 